\title{
PENGARUH DERAJAT DEASETILASI KHITOSAN DARI KULIT UDANG TERHADAP APLIKASINYA SEBAGAI PENGAWET MAKANAN
}

\author{
N. Rokhati*)
}

\begin{abstract}
Abstrak
Industri pengolahan udang banyak menimbulkan hasil samping berupa limbah kulit udang yang belum dimanfaatkan secara optimal, yaitu hanya dijadikan tepung dan campuran makanan ternak. Hal itu kurang memiliki nilai ekonomis dibandingkan dengan mengolahnya menjadi khitin dan khitosan. Khitosan banyak digunakan di berbagai industri. Salah satu penerapan khitosan yang penting dan dibutuhkan dewasa ini adalah sebagai pengawet bahan makanan pengganti formalin. Kualitas khitosan sering dinyatakan dengan besarnya nilai derajad deasetilasi. Penelitian ini bertujuan untuk menentukan kondisi operasi optimum proses deasetilasi khitin serta mempelajari pengaruh derajat deasetilasi terhadap khitosan sebagai bahan pengawet makanan. Proses deproteinisasi dengan larutan $\mathrm{NaOH}(3.5 \% \mathrm{w} / \mathrm{v})$ selama 2 jam pada suhu $65{ }^{\circ} \mathrm{C}$ dan proses demineralisasi dalam larutan $\mathrm{HCl}(1 \mathrm{~N})$ selama 30 menit pada suhu kamar. Proses deasetilasi dilakukan dengan memanaskan khitin dengan larutan $\mathrm{NaOH}(20 \%, 30 \%, 40 \%, 50 \%, 60 \%, 70 \%, 80 \% \mathrm{w} / \mathrm{v})$ pada suhu $\left(50{ }^{\circ} \mathrm{C}, 60{ }^{\circ} \mathrm{C}, 70{ }^{\circ} \mathrm{C}\right.$, $\left.80{ }^{\circ} \mathrm{C}, 90{ }^{\circ} \mathrm{C}, 100{ }^{\circ} \mathrm{C}, 110{ }^{\circ} \mathrm{C}\right)$ selama (1, 2, 3, 4, 5, 6, 7 jam). Parameter respon adalah derajat deasetilasi khitosan. Produk khitosan diaplikasikan untuk pengawet tahu dan analisa mikroba dilakukan dengan menggunakan metode TPC untuk mengetahui pengaruh derajat deasetilasi terhadap kemampuannya mengawetkan makanan. Hasil penelitian menunjukkan bahwa kondisi optimum proses deasetilasi khitin menjadi khitosan adalah pada konsentrasi $\mathrm{NaOH} 50 \%$ dan suhu $100^{\circ} \mathrm{C}$ selama 1 jam yang memberikan derajat deasetilasi sebesar 71,2\%.. Total bakteri pada perendaman tahu selama 3 hari dalam larutan asam asetat ditambah chitosan 6,8.104, dalam larutan asam asetat saja 9,9. 10 dan dalam blangko 8,6. 107, sehingga bisa disimpulkan bahwa khitosan dapat menghambat pertumbuhan bakteri. Namun meningkatnya derajad deasetilasi tidak begitu berpengaruh terhadap penurunan jumlah bakteri.
\end{abstract}

Kata kunci: kulit udang, chitosan, derajat deasetilasi, pengawet makanan.

\section{Pendahuluan}

Limbah kulit udang biasanya hanya dimanfaatkan untuk pakan ternak atau untuk industri makanan seperti pembuatan kerupuk udang. Limbah kulit udang mengandung bahan yang sangat berharga, yaitu khitin. Bahan ini apabila diproses lebih lanjut menghasilkan khitosan yang memiliki banyak manfaat dalam bidang industri. Khitosan merupakan bahan organik yang banyak digunakan di berbagai industri kimia. Salah satu penerapan khitosan yang penting dan dibutuhkan dewasa ini adalah sebagai pengawet bahan makanan pengganti formalin. Khitosan adalah bahan alami yang direkomendasikan untuk digunakan sebagai pengawet makanan karena tidak beracun dan aman bagi kesehatan. (Shahidi, 2005 dan Bautista-Banos, 2006).

Secara umum, cangkang kulit udang mengandung 27,6\% mineral, 34,9\% protein, $18,1 \%$ khitin , dan komponen lain seperti zat terlarut, lemak dan protein tercerna sebesar 19.4 \% (Suhardi, 1992). Oleh karena itu untuk memperoleh (isolasi) khitin dari cangkang udang melibatkan proses-proses pemisahan mineral (demineralisasi) dan pemisahan protein (deproteinasi). Proses deproteinasi untuk menghilangkan kandungan protein dalam bahan baku yang pada mulanya protein ini berikatan kovalen dengan khitin, menggunakan larutan basa $\mathrm{NaOH}$ panas dalam waktu yang relatif lama. Proses demineralisasi untuk menghilangkan garam-garam inorganik atau kandungan mineral yang ada pada khitin terutama $\mathrm{CaCO}_{3}$ menggunakan larutan asam $\mathrm{HCl}$ encer pada suhu kamar.

Khitin merupakan senyawa yang stabil terhadap reaksi kimia, tidak beracun (non toxic) dan bersifat biodegradable. Khitin tidak larut dalam air (bersifat hidrofobik), alkohol, serta tidak larut dalam asam maupun alkali encer. Khitin dapat larut dengan proses degradasi menggunakan asam-asam mineral pekat dan asam formiat anhidrous, namun tidak jelas apakah semua jenis khitin dapat larut dalam asam formiat anhidrous (Meyers dan Lee, 1989)

Khitin memiliki pengaturan 2,4-trans substituen dalam unit-unit monosakaridanya, dan sangat stabil terhadap umumnya reagensia, termasuk larutan alkali dalam air. Khitosan diketahui sebagai

\footnotetext{
*) Jurusan Teknik Kimia Fakultas Teknik UNDIP

Jl. Prof. Sudarto, SH, Tembalang-Semarang 50239

Telp.(024) 7460058
} 
khitin yang tiga dari empat gugus asetilnya dihilangkan. Perlakuan lama terhadap khitin dengan larutan $\mathrm{NaOH}$ pekat dan panas menghasilkan deasetilasi yang hampir sempurna tetapi produknya mengalami degradasi.

Dari khitin dapat dihasilkan khitosan dengan menghilangkan gugus asetil $\left(\mathrm{CH}_{3}-\mathrm{CO}\right)$ sehingga molekul dapat larut dalam larutan asam, proses ini disebut sebagai deasetilasi, yaitu menghasilkan gugus amina bebas (-NH) agar khitosan memiliki karakteristik sebagai kation. Secara umum derajat deasetilasi untuk khitosan sekitar $60 \%$, dan sekitar 90 - $100 \%$ untuk khitosan yang mengalami deasetilasi penuh. Harga ini tergantung dari bahan baku khitin yang digunakan dan proses yang dijalankan (Suhardi, 1992).
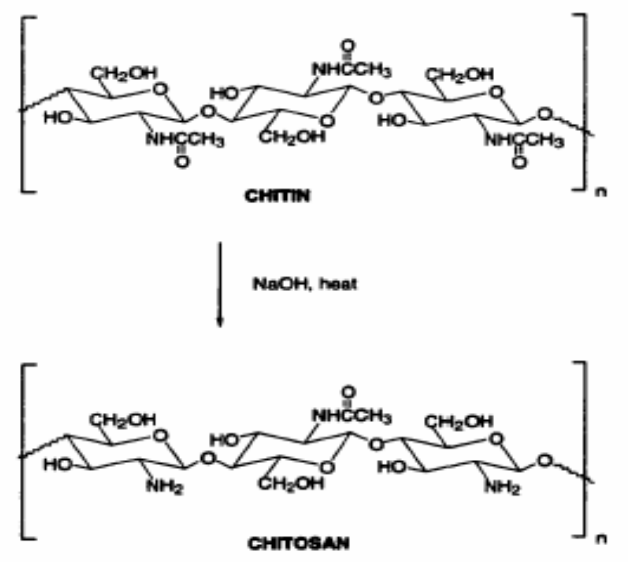

Gambar 1. Mekanisme Reaksi Pembentukan Chitosan dari Chitin

Khitosan merupakan padatan amorf berwarna putih dengan struktur kristal tetap dari bentuk awal khitin murni, memiliki sifat biologi dan mekanik yang tinggi diantaranya adalah biorenewable, biodegradable, dan biofungsional. Khitosan mempunyai rantai yang lebih pendek daripada rantai khitin.

Ikatan-ikatan amida lebih sulit membuka di bawah kondisi basa daripada gugus-gugus ester. Di bawah kondisi basa yang kuat, gugus asetat yang berdekatan dengan gugus hidroksil cis dapat mengalami $\mathrm{N}$-deasetilasi, tetapi gugus yang trans lebih resistansi (Suhardi, 1992).

Derajat deasetilasi pada pembuatan khitosan bervariasi dengan jumlah larutan alkali yang digunakan, waktu reaksi, dan suhu reaksi. Biasanya kualitas produk chitosan dinyatakan dengan besarnya nilai derajad deasetilasi (Muzzarelli,1985 dan Austin,1988). Penelitian ini bertujuan untuk menentukan kondisi optimum proses deasetilasi khitin limbah kulit udang menjadi khitosan dan pengaruh derajad deasetilasi terhadap aplikasinya sebagai pengawet tahu.

\section{Metode Penelitian}

Penelitian ini dilakukan melalui tiga tahap proses, yaitu tahap pembuatan khitin melalui proses deproteinasi dan demineralisasi, tahap deasetilasi, dan tahap aplikasi produk khitosan sebagai pengawet tahu.

Proses Deproteinasi dilakukan dengan menggunakan larutan 3,5\% (w/v) NaOH pada suhu $65{ }^{\circ} \mathrm{C}$ selama 2 jam dengan pengadukan konstan (1200 rpm), rasio sampel larutan $\mathrm{NaOH}$ 1:4. Proses demineralisasi dengan menggunakan larutan $\overline{\mathrm{HCl}(1}$ N) pada suhu kamar selama 30 menit dengan pengadukan konstan (1200 rpm), rasio sampel : larutan $\mathrm{HCl} 1$ : 4.

Proses Deasetilasi dengan menggunakan rasio sampel : larutan $\mathrm{NaOH}=1: 25(\mathrm{gr} / \mathrm{ml})$, pengadukan konstan $1200 \mathrm{rpm}$ dan berbagai variabel berubah :

$>$ Waktu (jam) : 1, 2, 3, 4, 5, 6,7

$>$ Konsentrasi $\mathrm{NaOH}(\%): 20,30,40,50,60$, 70,80

$>$ Suhu $\left({ }^{\circ} \mathrm{C}\right): 50,60,70,80,90,100,110$

Ketiga tahap proses tersebut diakhiri dengan proses pencucian, penyaringan dan pengeringan.

Hasil dari proses deasetilasi khitin untuk menghasilkan khitosan tersebut dianalisa derajat deasetilasinya (\% DD-nya) menggunakan analisa FTIR dengan menggunakan metode garis Moore dan Robert dengan menggunakan persamaan dibawah ini (Avadi et al., 2004):

$$
D D=\frac{1-A_{3410}}{A_{1588}} \times \frac{1}{1.33}
$$

Dengan :

$$
\begin{aligned}
&\text { Nilai A(Absorbansi })=\log (\mathrm{Po} / \mathrm{P}) \\
& \mathrm{A}_{3410}= \text { Absorbansi pada panjang gelombang } \\
& 3410 \mathrm{~cm}^{-1} \text { untuk serapan gugus } \\
& \text { hidroksi/amin }\left(-\mathrm{OH},-\mathrm{NH}_{2}\right) \\
& \mathrm{A}_{1588}= \text { Absorbansi pada panjang gelombang } \\
& 1588 \mathrm{~cm}^{-1} \text { untuk serapan gugus } \\
& \text { asetamida }\left(\mathrm{CH}_{3} \mathrm{COONH}-\right)
\end{aligned}
$$

Analisa optimasi proses hasil analisa derajat deasetilasi menggunakan cara grafis secara bertahap. Sedangkan untuk pengaruh derajat deasetilasi chitosan terhadap pengawetan makanan dilakukan dengan perendaman tahu pada 5 gram chitosan dalam 1 liter larutan asam asetat 1\%. Penghitungan jumlah klon bakteri pada sampel tahu menggunakan metode TPC (total plate count)

\section{Hasil Dan Pembahasan}

Dari gambar 2 dapat dilihat bahwa semakin tinggi konsentrasi $\mathrm{NaOH}$ maka derajat deasetilasinya juga semakin tinggi. Proses deasetilasi (penghilangan gugus asetil) khitin berlangsung dalam kondisi basa karena gugus $\mathrm{N}$-asetil tidak dapat dihilangkan dengan reagensia asam tanpa hidrolisis polisakaridanya. Mula-mula terjadi reaksi adisi, dimana gugus $\mathrm{OH}^{-}$ masuk ke dalam gugus $\mathrm{NHCOCH}_{3}$ kemudian terjadi eliminasi gugus $\mathrm{CH}_{3} \mathrm{COO}^{-}$sehingga dihasilkan suatu amida yaitu khitosan. Ikatan-ikatan amida lebih sulit membuka di bawah kondisi basa daripada gugusgugus ester. 


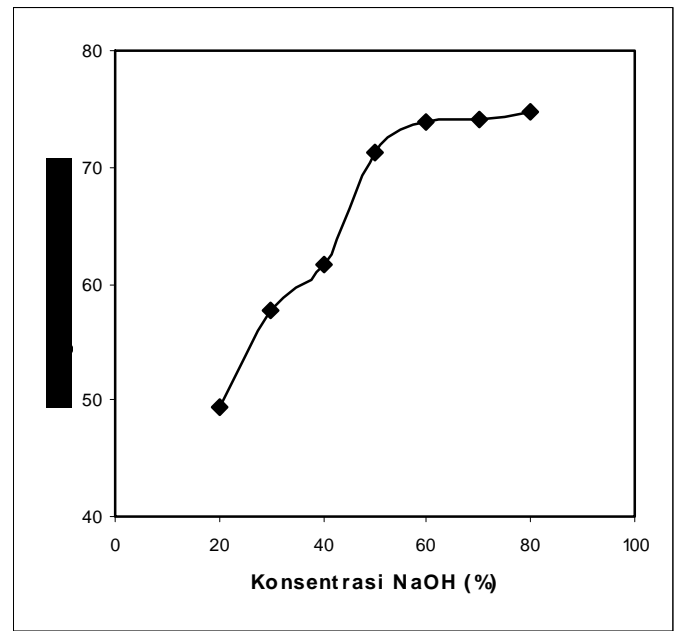

Gambar 2. Grafik Hubungan Konsentrasi $\mathrm{NaOH}$ terhadap \% Derajat Deasetilasi

Di bawah kondisi basa yang kuat, gugus asetat yang berdekatan dengan gugus hidroksil cis dapat mengalami N-deasetilasi, tetapi gugus yang trans lebih resistansi (Suhardi, 1992). Konsentrasi $\mathrm{NaOH}$ yang semakin tinggi, menyumbangkan gugus $-\mathrm{OH}$ yang semakin banyak, sehingga gugus $\mathrm{CH}_{3} \mathrm{COO}^{-}$yang tereliminasi juga semakin banyak dan menghasilkan gugus amida yang semakin banyak. Hal ini diindikasikan dengan kenaikan derajat deasetilasi.

Nilai derajat deasetilasi yang optimum adalah pada konsentrasi $\mathrm{NaOH} 50 \%$ yang menghasilkan chitosan dengan \% DD $=71,2 \%$. Pada penelitian selanjutnya, dilakukan pada variabel konstan konsentrasi $\mathrm{NaOH} 50 \%$.

Pengaruh suhu terhadap derajad deaseilasi (gambar 3) menunjukan bahwa semakin besar suhu maka derajat deasetilasinya juga semakin besar. Semakin tinggi suhu akan meningkatkan kecepatan reaksi dalam deasetilasi molekul khitin menjadi khitosan. Hal ini disebabkan suhu yang semakin tinggi akan membuat ikatan antar sesama molekul menjadi lemah, viskositas menjadi rendah dan molekul molekul bergerak lebih cepat sehingga gugus - $\mathrm{OH}$ dari larutan $\mathrm{NaOH}$ akan lebih cepat beradisi dengan gugus $\mathrm{NHCOCH}_{3}$ pada khitin, mengeliminasi gugus asetil dan gugus amina bebasnya akan berikatan menjadi amida (Shahidi, 2005). Hal ini sesuai dengan persamaan Arrhenius:

$$
k=A \cdot e^{-E a / R T}
$$

Dengan :
k : konstanta kecepatan reaksi
$\mathrm{R}$ : konstanta gas ideal
A : faktor tumbukan
$\mathrm{T}$ : suhu
Ea : energi aktivasi

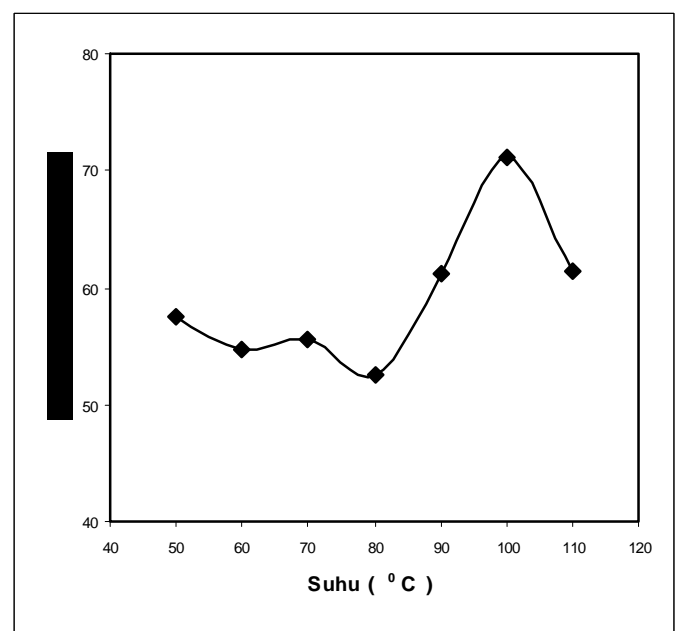

Gambar 3. Grafik Hubungan Suhu terhadap \% Derajat Deasetilasi

Dari gambar 3, didapat suhu operasi optimum adalah pada suhu operasi $100^{\circ} \mathrm{C}$. Tetapi pada suhu $110^{\circ} \mathrm{C}$, terlihat bahwa derajat deasetilasinya lebih rendah daripada suhu $100^{\circ} \mathrm{C}$. Artinya bahwa gugus asetil yang tereliminasi/terlepas dari gugus $\mathrm{NHCOCH}_{3}$ pada khitin lebih sedikit. Hal ini disebabkan karena adanya pengaruh suhu tinggi juga menyebabkan proses depolimerisasi/degradasi khitin (Shahidi, 2005).

Semakin lama waktu proses maka reaksi akan berlangsung semakin lama sehingga molekul $\mathrm{NaOH}$ yang teradisi ke molekul khitin semakin banyak dan menyebabkan gugus asetil yang terlepas pun semakin banyak. Namur lamanya waktu juga menyebabkan terjadinya degradasi khitosan (yang ditandai dengan menurunnya viskositas), sehingga lamanya waktu proses tidak begitu berpengaruh terhadap derajad deasetilasi (Shahidi, 2005). Dari gambar 4 dapat dilihat bahwa waktu operasi proses deasetilasi menghasilkan derajat deasetilasi yang bervariasi. Naik turunnya \% DD seiring dengan perubahan waktu menandakan bahwa deasetilasi dan degradasi khitosan berlangsung secara bersamaan. Nilai \% DD tertinggi diperoleh pada satu jam pertama.

Semakin meningkatnya \% DD menyebabkan semakin banyaknya gugus asetil yang terlepas atau semakin banyaknya gugus aktif amida bebas $\left(-\mathrm{NH}_{2}\right)$ yang terdapat dalam molekul khitosan yang memberikan efek antimicrobial karena dapat membentuk polikation yang memiliki afinitas yang kuat terhadap sell bakteri (Rabea, et al., 2003). Tetapi pada tabel 1 menunjukan bahwa seiring dengan peningkatan \% DD tidak selalu menyebabkan terjadinya penurunan total jumlah bakteri yang ada. Hal ini berarti ada pengaruh lain selain \% DD (diantaranya $\mathrm{pH}$ larutan) yang dapat mempengaruhi aktivitas antimicrobial. 


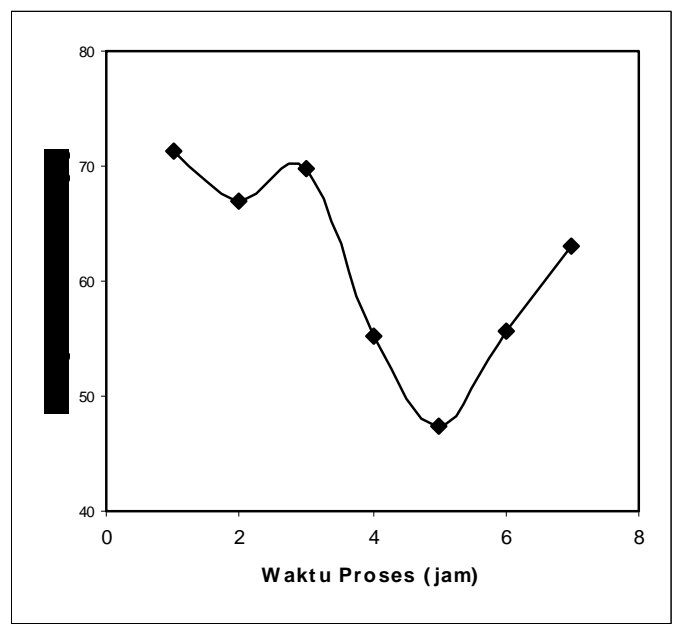

Gambar 4. Grafik Hubungan Waktu terhadap \% Derajat Deasetilasi
Mekanisme aktivitas antimikrobial khitin dan khitosan masih belum diketahui secara pasti. Akan tetapi salah satu mekanisme yang mungkin terjadi yaitu molekul khitosan memiliki kemampuan untuk berinteraksi dengan senyawa pada permukaan sell bakteri kemudian teradsorbsi membentuk semacam layer. Proses ini dapat terjadi secara fisik, $\mathrm{pH}$ pada permukaan membran sell bakteri mendekati netral yang menyebabkan khitosan mengalami presipitasi dan menempel pada permukaan membentuk semacam lapisan (layer) yang tidak dapat dilalui substansi essensial sell dan menghambat saluran transportasi sell sehingga sell mengalami kekurangan substansi untuk berkembang dan mengakibatkan matinya sell (Ralston, et al., 1964).

Tabel 1. Hasil Pemeriksaan Bakteriologis Tahu

\begin{tabular}{|c|c|c|c|c|}
\hline No & Sampel & $\begin{array}{c}\text { Total Bakteri } \\
\text { (Perendaman 1 hari) } \\
(\text { sel/gr) }\end{array}$ & $\begin{array}{c}\text { Total bakteri } \\
\text { (Perendaman 2 hari) } \\
\text { (sel/gr) }\end{array}$ & $\begin{array}{c}\text { Total bakteri } \\
\text { (Perendaman 3 hari) } \\
\text { (sel/gr) }\end{array}$ \\
\hline 1 & $\mathrm{~L}$ & $7,3 \times 10^{3}$ & $1,37 \times 10^{4}$ & $6,8 \times 10^{4}$ \\
\hline 2 & $\mathrm{M}$ & $2,28 \times 10^{3}$ & $1,32 \times 10^{4}$ & $8,4 \times 10^{3}$ \\
\hline 3 & $\mathrm{~N}$ & $2,45 \times 10^{3}$ & $1,40 \times 10^{4}$ & $9,9 \times 10^{4}$ \\
\hline 4 & $\mathrm{O}$ & $4,2 \times 10^{4}$ & $7,4 \times 10^{5}$ & $9,9 \times 10^{5}$ \\
\hline 5 & $\mathrm{P}$ & $8,7 \times 10^{5}$ & $2,4 \times 10^{7}$ & $8,6 \times 10^{7}$ \\
\hline
\end{tabular}

Keterangan : $\quad$ tahu direndam dalam 5 gram chitosan dalam 1 liter larutan asam asetat $1 \%$
$\mathrm{L} \quad=$ Chitosan $71.2 \% \mathrm{DD}$
$\mathrm{M} \quad=$ Chitosan 42,2 \% DD
$\mathrm{N} \quad=$ Chitosan $55.6 \% \mathrm{DD}$
$\mathrm{O}=$ larutan asam asetat tanpa chitosan
$\mathrm{P}=$ Blangko

Total bakteri $<10^{6}$ masih aman untuk dikonsumsi ( FAO:1979 )

Tabel 2. Perbandingan produk chitosan yang dihasilkan dengan standar baku Chitosan yang berlaku

\begin{tabular}{|c|c|c|}
\hline Spesifikasi & Standar Chitosan & Chitosan yang dihasilkan \\
\hline Deasetilasi & $\begin{array}{c}\geq 70 \% \text { jenis teknis dan } \\
>95 \% \text { jenis pharmasikal }\end{array}$ & $71.2 \%$ \\
\hline Kadar abu & Umumnya $<1 \%$ & $0,6 \%$ \\
\hline Kadar air & $2-10 \%$ & $4 \%$ \\
\hline Kelarutan & Hanya pada $\mathrm{pH} \leq 6$ & Pada $\mathrm{pH} \leq 6$ \\
\hline Kadar nitrogen & $7-8,4 \%$ & $-10,2 \%$ \\
\hline Warna & Putih sampai kuning pucat & Kuning pucat \\
\hline Ukuran partikel & 5 ASTM Mesh & - \\
\hline E. Coli & Negatif & Negatif \\
\hline Salmonella & Negatif & Negatif \\
\hline
\end{tabular}


Kemampuan membentuk lapisan (layer) ini sangat dipengaruhi oleh berat molekul dan \% DDnya. Pada \% DD yang rendah ternyata adsorpsi berlangsung lebih baik dan dapat membentuk lapisan (layer) permukaan lebih efektif walaupun dengan muatan densitas yang rendah atau jumlah amida yang terbentuk relatif lebih sedikit (Strand et al., 2003). Hal ini menegaskan bahwa tidak selalu seiring dengan peningkatan \% DD dapat menurunkan jumlah total bakteri yang terhitung. Meningkatnya nilai \%DD dapat meningkatkan kelarutan khitosan (Qin-Caiqin et al., 2005), sehingga memper-mudah penggunaan produk khitosan.

Namun dari tabel 1 terlihat bahwa sampel tahu yang direndam dalam larutan asam asetat ditambah khitosan mengandung bakteri yang lebih sedikit $\left(6,8.10^{4}\right.$ sel/gram) dibanding dengan tahu yang hanya direndam dalam larutan asam asetat $\left(9,9 \cdot 10^{5}\right)$. Dilihat dari jumlah bakteri yang terhitung melalui metode TPC memperlihatkan bahwa semua sampel berada dibawah $10^{6}$ jumlah total bakteri yang menunjukan aman untuk dikonsumsi untuk produk serealia dan olahannya yang diperbolehkan oleh FAO.

Dari tabel 2 terlihat bahwa kecuali kadar nitrogen, produk khitosan yang dihasilkan telah memenuhi standar yang berlaku. Namun dari hasil analisa mikroba menunjukkan bahwa khitosan dengan kandungan nitrogen yang melebihi standart mutu masih bagus untuk digunakan sebagai bahan pengawet makanan.

\section{Kesimpulan}

- Kondisi optimum proses deasetilasi khitin menjadi khitosan adalah pada konsentrasi $\mathrm{NaOH} \mathrm{50 \%} \mathrm{dan}$ suhu $100^{\circ} \mathrm{C}$ selama 1 jam yang memberikan derajat deasetilasi sebesar $71,2 \%$.

- Total bakteri pada perendaman tahu selama 3 hari dalam larutan asam asetat ditambah chitosan dengan derajat deasetilasi $71,2 \%$ adalah $6,8.10^{4}$, dalam larutan asam asetat saja 9,9. 105 , dan dalam blangko 8,6. $10^{7}$.

- Meningkatnya derajad deasetilasi tidak begitu berpengaruh terhadap penurunan jumlah bakteri pada bahan makanan

\section{Daftar Pustaka}

Austin, P.R, Brine, C.J Castle, J.C., and Zikakos, J.P., (1988), "Chitin New Facets of Research” J. Food Sci, Vol.54.

Avadi, M.R., Mahdavia, G., Sadhegi, A.M., Erfan, M., Amini, M., Tehrani, M.R., and Shaflee,A., (2004), "Synthesis and Characterization of N-Diethyl Methyl Chitosan” Iranian Polymer Journal, 13 (5), hal. 431-430.

Bautista-Banos, A.N., Hernandez-Lauzardo, M.G., and Velazquez-del Valle, (2006), "Chitosan as a potential natural compound to control pre and postharverst diseases of horticultural commodities", Crop Protection, Elsevier Ltd, hal. 108 - 118.

Meyers, S.P., \& Lee, K.S., (1989), "Isolation and characterization of chitin from crawfish shell waste”, J.Agric Food Chem, 37, 575

Muzzarelly, (1985), "Studies on The Suitable of Chitinocistic Microorganism for Shrimp Waste Fermentation", Dissertation, University of Washington, New York.

Qin-caiqin, Li. Huirong, \& Liu.Yi ,(2005), ”Water Solubility of Chitosan and its antimicrobial activity,“. Elsevier.

Strand, S.P., Varum, K.M., and Ostgaard, K., (2003), 'Intractions Between Chitosans and Bacterial Suspensions: Adsorption and Flocculation“, Colloids and Surface B: Biointerface, 27, 71-81.

Rabea, E.E., Badawy, M.E.T., Stevens, C.V., Smagghe, G., and Steurbout, W., (2003), “ Chitosan as Antimicrobial agent: Aplications and Mode of Action”, Biomacromolecules, 4, 1457-1465.

Ralston, G.B., Tracey, M.V. and Wrench, P.M., (1964),"The inhibition of Fermentation in Baker's Yeast by Chitosan”, Biochimica et Biophysica Acta, 93, 652-655.

Shahidi, F. and Abuzaytun, R., (2005), "Chitin, Chitosan, and Coproduct: Chemistry, Production, Application, and health Effect", Department of Biochemistry, Memorial University of Newfoundland, St. John's, Canada.

Suhardi, (1992), “Khitin dan Khitosan”, Pusat Antar Universitas Pangan dan Gizi UGM, Yogyakarta. 